\title{
Archaeological implications of ethnographically grounded functional study of pottery from Nyanga,
} Zimbabwe

Robert T. Nyamushosho ${ }^{1 *} \&$ Shadreck Chirikure ${ }^{1,2^{*}}$

Mailing address

${ }^{1}$ Materials Laboratory, Department of Archaeology, University of Cape Town, 7701, South Africa

${ }^{2}$ School of Archaeology, University of Oxford, 1 South Parks Road, Oxford OX1 3TG, England

* Corresponding authors: Robert T. Nyamushosho and Shadreck Chirikure

E-mail: Emails nymrob001@myuct.ac.za (R.T Nyamushosho) and shadreck.chirikure@uct.ac.za (S.

Chirikure)

\begin{abstract}
The value of typological analyses of pottery in global archaeology is widely acknowledged. However, pottery typologies in southern Africa are frequently criticised for one-dimensionally revealing more about decorations on pots and not their function and meaning to people that made and used them. This motivated an experiment to combine functional and stylistic variables of pottery from modernday Nyanga district, in north-eastern Zimbabwe to develop alternative ways of approaching archaeological pottery. With the alertness that the present and the past are different, even in contexts of strong cultural continuity, we applied the results of the experiment to a collection of archaeological pottery from Nyanga tradition (CE 1300 -1900) sites. For the recent past, the study indicated that vessel shapes strongly correlated with names and functions of pottery across the mundane, ritual and symbolic worlds. Comparisons with the archaeological picture identified a similarity of shapes between the past and the present. This stimulated reflections on a wide array of quotidian roles and functions that pottery fulfilled for Nyanga populations in the deep past. The conclusion to the paper is that functional classifications, particularly when combined with style, are a strong alternative to dominant classification schemes which enlighten more on people and not the vessels. However, the robustness of such an approach must be firmed up with the application of techniques from the material, chemical, and molecular techniques to develop a holistic view of pottery and its role in everyday practice at individual, community and societal levels.
\end{abstract}

Keywords: Functional typology, Nyanga pottery, Experimental archaeology, African centred knowledge

\section{Introduction}

For ceramics to be relevant in the Southern African Iron Age, archaeologists must broaden their theoretical base to include social and other contexts when interpreting material culture items such as pottery" (Lindahl and Pikirayi, 2013:455).

Globally, pottery forms some of the largest categories of material evidence recovered from archaeological sites. Consequently, ceramics continue to be extensively studied by archaeologists to develop localised and regional sequences and to explore cultural practices of past societies. Archaeologists in southern Africa have constructed local and regional taxonomies and sequences based on decorative style and shape profiles of pottery (e.g. Posnansky, 1961; Robinson, 1966; Soper, 1971, 2002; Denbow, 1983; Sinclair, 1987; Pikirayi 1993, 2001; Pwiti, 1996; Phillipson, 2005; 
Huffman, 2007). However, though insightful in tracing the settlement history of several Iron Age communities in southern Africa, most of these etic typological analyses were undertaken using Anglo-American analytical frameworks that prioritised pottery style and decoration to the extent of excluding other pertinent information such as possible uses (see Hall 1983, 1984; Pikirayi, 2007 for critique). The major shortcoming of such an approach was that local classifications, meanings, and uses of pottery were lost. Even in cases where attempts were made to apply emic approaches (e.g. Huffman, 1972), the outcome was converted into hard archaeology facts, at odds with community understanding. This made pottery passive objects in the articulation of everyday life (see Pikirayi, 2007 for critique).

Ndoro (1996) and other archaeologists working in southern Africa (Hall, 1983, 1984; Collett, 1993; Lindahl and Matenga, 1995) expressed strong dissatisfaction with the way typologies constructed by archaeologists marginalised local meanings, local worldviews and local values rendering them nearly useless in the eyes of local people. Because the world of archaeologists was often far apart from that of native people, Ndoro advocated for an approach to pottery that draws local meanings into the centre of analyses (see also David et al., 1988; Gosselain, 1992; Collett, 1993; for similar arguments). The experimental study discussed in this paper focused on pottery from modern and precolonial Nyanga (Fig. 1) and is an attempt to develop a classification understandable by both natives and archaeologists. Nyanga which is situated in north-eastern Zimbabwe is home to the Saunyama, Manyika and Hwesa communities. It is one of the unique and ancient cultural landscapes (CE 1300 1900) associated with intensified agricultural systems of the later Iron Age (see Randall-Maclver, 1906; Summers, 1958; and Soper, 2002 for comprehensive archaeological details). Nyanga was attractive for our work because there is a well-established culture-historical sequence largely based on pottery typology and few radiocarbon dates (Summers, 1958; Manyanga, 1995; Soper, 2002). The sequence showed that Nyanga was occupied by farming populations from CE 300 onwards. However, from around CE 1300, populations who made pottery different from that used in the first millennium and made a huge labour investment to build agricultural terraces became prominent in Nyanga (Soper, 2002). Historians and archaeologists have connected through oral traditions genealogical links between modern groups that live in Nyanga and those responsible for terraces and other infrastructure (Bhila, 1982; Maxwell, 1999; Mupira, 2001; Soper, 2002; Beach, 2002; Nyamushosho, 2013).

Fig. 1. Map of modern day Nyanga showing contemporary ethnic groups and the distribution of archaeological sites with pottery used in this study.

Leveraging on existing typological work, this paper combines functional and stylistic variables of pottery from modern-day Nyanga to develop alternative ways of understanding archaeological pottery recovered from the same area. An experimental study was made to develop a functional typology of modern pottery informed by participant observation and interviews. Subsequently, the outcome classification was applied to archaeological pottery for comparative purposes. In conformity with a methodology that we applied elsewhere (see Chirikure et al., 2017), the results were taken back to communities for feedback and validation. The next section focuses on the methods adopted in the research.

\section{Methods}

This study was performed in a stepped but iterative methodology beginning with an ethnographic inspired functional typological classification of pots followed by an application of the results to the archaeology as follows: 


\section{Ethnographic study}

An archival study of published and unpublished data was performed to identify the names and functions of pottery used by Shona people in and around Nyanga. This was augmented with our experiential knowledge of growing up, in various Shona communities and using pottery. We developed a database with names of pottery, their form, functions as well as their changing contexts of use. Based on this information, we performed ethnographical research amongst the Manyika, Saunyama and Hwesa communities in Nyanga basing on the fact that their ancestry is historically related to the ancient terrace-builders of Nyanga (see Summers, 1958; Bhila, 1982; Maxwell, 1999; Mupira, 2001; Beach, 2002; Soper, 2002; Nyamushosho, 2017). An effort was made to explore how local people classify pots. The fieldwork was iterative. It combined personal interviews with participant observation to record names of pottery used for cooking, storage, serving food and much more. Furthermore, metric and morphological attributes of the different pot categories were captured. In a modified Delphi approach (see Chirikure et al., 2017), we took the results of our study back to the communities for discussion, substantiation, and validation. We held focus group discussions at the homestead of the incumbent Chief Saunyama where more than twelve elders were gathered including the local potters who are the keepers of pottery knowledge. Several amendments were made after the intervention of communities especially in terms of functional classes and multiple contexts of use. The result is a more balanced outcome that corrected through community peer review, information that we had generated.

\section{The archaeological sample and approach}

The study relied on published assemblages of Nyanga pottery recovered from ten archaeological sites belonging to the terrace-builders in precolonial Nyanga (Table 1; Fig. 1) (Randall-Maclver, 1906; Mason, 1933; Martin, 1937; Summers, 1958; Soper, 2002; Musindo, 2005; Shenjere, 2011; Manyanga and Shenjere, 2012). Random sampling was employed to make sure that most of the sites that were previously inhabited by the terrace-builders of Nyanga were sampled. Ultimately, a total of 103 potsherds (Table 1; Fig. 2) were chosen for further analysis informed by whether shapes could be reconstructed and whether they were complete or not using Adobe Illustrator. It is much easier to identify shapes with fragments that are nearer to complete vessels.

Table 1: Sites where study samples were recovered

To standardise the result, sampled pottery from the selected sites was studied using dominant etic typological approaches used in southern Africa Iron Age studies focusing on key anatomical features (i.e. lips, rims, shoulders, body and base) that define a vessel shape (see Soper, 1971, 2002; Summers, 1958; Pikirayi, 1993; Huffman, 2007). The resulting classes were compared to those coming out of our ethnographically grounded approach for creating comparative points for discussion.

Fig 2. Part of the sampled pottery from the selected Nyanga tradition sites 


\section{Results}

2.1. Functional typological classification of pottery used by contemporary Manyika, Saunyama and Hwesa peoples

The observations gathered during the ethnographic study were combined and are presented in Table 2. Basically, the pots are broadly classified under three (primary) functional categories. The first category comprised of culinary vessels. These form the majority of the Saunyama, Manyika, and Hwesa pottery and are used as cookware, to prepare food (see Table 2). Most culinary pots had no necks to facilitate steering when cooking (Martin, 1941; Stead, 1947; Gelfand, 1974, 1977; Gelfand, et al., 1985; Jacobson-Widding, 1992; Fredriksen, 2009; Nyamushosho, 2012). Their shapes and size vary and range according to respective functions (Table 2) and the size of the family. Usually, these ranged between the small and medium, sized for effective heat transfer. As demonstrated in Table 2, pottery used for cooking is rarely decorated among the Manyika, Saunyama, and Hwesa and this is common in the broader Shona worldview (Schofield, 1948; Lawton, 1965; Ellert, 1984; Aschwanden, 1989, Collett, 1993; Ndoro, 1996; Lindahl and Pikirayi 2013).

Brewing vessels are another functional category we recorded among the Manyika, Saunyama and Hwesa household vessels. Since the precolonial era in Nyanga mhamba (opaque alcoholic beer made from fermented millet or sorghum) and magada (opaque non-alcoholic beer made from fermented millet or sorghum) beverages have always occupied the centre stage of the Saunyama, Manyika, and Hwesa liquid foods. As a result, the traditional brewing vessels (hari dzedoro) presented in Table 2 and Fig. 3, have been always produced in large numbers to enable brewing of mhamba and magada which are usually consumed as 'cool drinks' on daily basis and during occasional functions such as nhimbe (work parties), and ndari (beer parties). Most of the brewing vessels recorded were tall, wide, and could accommodate large volumes of beer (Fig. 3). Such vessels were designed with thick walls to hold the liquid. Basically, gate and mbiziro are generally undecorated.

Lastly, we identified several large and medium-sized pottery vessels that were used in most homesteads for storing, transporting and serving both liquid and solid foods (see Table 2 and Fig. 3). Typical dry and wet-foods stored (for weeks or months) in these pots and bowls included upfu (maize meal), cereals, legumes, spices (zvirungo), vegetable or animal fat (mafuta), salt (munyu), curdled milk (mukaka wakakora) and beer. Basing on the average metric attributes we recorded during our ethnographic survey, the diameter and height dimensions of some large vessels such as denhe, enabled them to hold up to $50 \mathrm{~kg}$ of cereal. Other water-fetching vessels like musudze were occasionally decorated on their shoulders or necks with incised triangle motifs or lattice patterns of vertical and horizontal ridges/ribs locally known as mitwi. Basically, large vessels such as musudze and denhe had thickened walls for storage reinforcement purposes and similarly to brewing vessels, they were also designed with large necks to facilitate the pouring of liquids. Bowls on the other hand particularly those used for serving food for an individual or more people such as nhera were designed with open mouths. Local names and metric attributes of most of these vessels corresponded with those identified more than 50 years ago amongst the Manyika by previous ethnographers such as Martin (1941), Stead (1947) and Lawton (1965) (see Fig. 4.) 
Table 2. Characteristics of Manyika, Saunyama and Hwesa pottery including functions and types.

\begin{tabular}{|c|c|c|c|c|c|c|c|}
\hline \multirow[t]{2}{*}{$\begin{array}{l}\text { Vessel } \\
\text { Class }\end{array}$} & \multicolumn{2}{|r|}{ Typology } & \multicolumn{2}{|c|}{$\begin{array}{c}\text { Metric } \\
\text { Attributes }\end{array}$} & \multirow[t]{2}{*}{$\begin{array}{c}\text { Decoratio } \\
\mathrm{n}\end{array}$} & \multicolumn{2}{|c|}{ Function } \\
\hline & Emic & Etic & $\begin{array}{l}\text { Diam } \\
\text { eter } \\
\text { range }\end{array}$ & $\begin{array}{l}\text { Height } \\
\text { range }\end{array}$ & & Primary & Secondary \\
\hline \multirow[t]{4}{*}{$\begin{array}{l}\text { Culinary } \\
\text { vessels }\end{array}$} & $\begin{array}{l}\text { *Hweng } \\
\text { a } \\
\text { / } \\
\text { Chayeng } \\
\text { a } \\
\text { /Gango }\end{array}$ & $\begin{array}{l}\text { Open shallow } \\
\text { bowl with out- } \\
\text { turning or straight } \\
\text { rim/ Sizeable } \\
\text { broken potsherd }\end{array}$ & $\begin{array}{c}10-15 \\
\mathrm{~cm}\end{array}$ & $5-7 \mathrm{~cm}$ & No & $\begin{array}{c}\text { Used for roasting } \\
\text { mhandire (roasted maize), } \\
\text { nzungu (groundnuts, or } \\
\text { nyimo (bambara } \\
\text { groundnuts). }\end{array}$ & $\begin{array}{l}\text { Used as platter transporting } \\
\text { hot ambers to make fire, } \\
\text { feeding dogs and cats }\end{array}$ \\
\hline & $\begin{array}{l}\text { *Mbiya } \\
\text { / } \\
\text { Chigapu } \\
\text { / } \\
\text { Hadyan } \\
\text { a } \\
\text { /Chikari }\end{array}$ & $\begin{array}{l}\text { Small wide- } \\
\text { mouthed pot with } \\
\text { out-turning rim/ } \\
\text { Medium/neckless } \\
\text { pot/ } \\
\text { constricted pot } \\
\text { with in-sloping } \\
\text { rim/ Small deep } \\
\text { bowl with straight } \\
\text { rim/ Small } \\
\text { hemispherical } \\
\text { bowl with straight } \\
\text { rim/ Small necked } \\
\text { bowl with out- } \\
\text { turning rim/ } \\
\text { Medium open } \\
\text { bowl without- } \\
\text { turning or straight } \\
\text { rim }\end{array}$ & $\begin{array}{l}19-26 \\
\mathrm{~cm}\end{array}$ & $\begin{array}{l}9-22 \\
\mathrm{~cm}\end{array}$ & $\begin{array}{l}\text { Occasiona } \\
\text { lly } \\
\text { decorated } \\
\text { with } \\
\text { graphic } \\
\text { designs } \\
\text { such as } \\
\text { cross } \\
\text { hatching }\end{array}$ & $\begin{array}{l}\text { Used for cooking usavi } \\
\text { (relish) made of } \\
\text { vegetables such as derere } \\
\text { (okra), hohwa } \\
\text { (mushroom) nhungumira } \\
\text { (blackjack), mutikiti } \\
\text { (pumpkin leaves), } \\
\text { muferefere (melon } \\
\text { leaves), nyevhe (Cleome } \\
\text { gynandra), and mowa } \\
\text { (amaranthus) }\end{array}$ & $\begin{array}{l}\text { Occasionally used for serving } \\
\text { usavi }\end{array}$ \\
\hline & $\begin{array}{l}\text { Chimbiy } \\
\text { a } \\
\text { /Kadodo }\end{array}$ & $\begin{array}{l}\text { Small constricted } \\
\text { bowl with in- } \\
\text { sloping or out } \\
\text { turning rim/ Small } \\
\text { open bowl } \\
\text { without-turning or } \\
\text { straight rim/ Small } \\
\text { neckless pot with } \\
\text { out-turning rim/ } \\
\text { Open bowl with } \\
\text { out- turning or } \\
\text { straight rim }\end{array}$ & $\begin{array}{l}11-16 \\
\mathrm{~cm}\end{array}$ & $\begin{array}{l}7-10 \\
\mathrm{~cm}\end{array}$ & No & $\begin{array}{l}\text { Used for preparing } \\
\text { children's porridge (bota) } \\
\text { Also used for serving } \\
\text { usavi (vegetables or } \\
\text { meat) }\end{array}$ & $\begin{array}{l}\text { Used for cooking a small } \\
\text { quantity of usavi }\end{array}$ \\
\hline & $\begin{array}{l}\text { Mukate } \\
\text { / } \\
\text { Shamba } \\
\text { kodzi } \\
\text { / } \\
\text { Tsambak } \\
\text { odzi } \\
\text { /Tsaiya }\end{array}$ & $\begin{array}{l}\text { Medium wide- } \\
\text { mouthed pot with } \\
\text { out-turning rim/ } \\
\text { Medium necked } \\
\text { bowl with out- } \\
\text { turning rim }\end{array}$ & $\begin{array}{l}22-30 \\
\mathrm{~cm}\end{array}$ & $\begin{array}{c}16-27 \\
\mathrm{~cm}\end{array}$ & & $\begin{array}{l}\text { Used for cooking porridge } \\
\text { or sadza (stiff porridge) } \\
\text { made of mapfunde } \\
\text { (sorghum), rukweza/njera } \\
\text { (finger millet), njeke } \\
\text { (maize), or mhunga } \\
\text { (bulrush millet) }\end{array}$ & $\begin{array}{l}\text { Also used to prepare nhopi } \\
\text { (mushed pumpkin mixed } \\
\text { with peanut butter), } \\
\text { manhuchu (samp) as well as } \\
\text { legume and tuber foods such } \\
\text { as fondokoto (cowpeas), } \\
\text { nyimo (ground beans), } \\
\text { magogoya (colocasia } \\
\text { varirty), madhumbe (yams), } \\
\text { mufarinya (cassava), majo } \\
\text { (colocasia variety), tsenza } \\
\text { (livingstone potato) and } \\
\text { manhanga (pumpikins }\end{array}$ \\
\hline $\begin{array}{l}\text { Brewing } \\
\text { vessels }\end{array}$ & $\begin{array}{l}\text { Gate } \\
\text { / } \\
\text { Chikang } \\
\text { a }\end{array}$ & $\begin{array}{l}\text { Large necked pot } \\
\text { with out-turning } \\
\text { rim }\end{array}$ & $\begin{array}{l}30-50 \\
\mathrm{~cm}\end{array}$ & $\begin{array}{l}40-100 \\
\mathrm{~cm}\end{array}$ & $\begin{array}{l}\text { Occasiona } \\
\text { lly } \\
\text { decorated } \\
\text { with } \\
\text { bands of } \\
\text { puncates }\end{array}$ & $\begin{array}{l}\text { Used for brewing } \\
\text { mhamba (malting and } \\
\text { souring) }\end{array}$ & $\begin{array}{l}\text { Sometimes used for as a silo } \\
\text { for storing grain such as } \\
\text { mapfunde, rukweza/njera, } \\
\text { njeke, mhunga, mupunga, } \\
\text { fondokoto, and nyimo as well } \\
\text { as storing water }\end{array}$ \\
\hline
\end{tabular}




\section{Continuation of Table 2.}

\begin{tabular}{|c|c|c|c|c|c|c|c|}
\hline \multirow[t]{2}{*}{$\begin{array}{l}\text { Vessel } \\
\text { Class }\end{array}$} & \multicolumn{2}{|r|}{ Names } & \multicolumn{2}{|c|}{$\begin{array}{c}\text { Metric } \\
\text { Attributes }\end{array}$} & \multirow[t]{2}{*}{$\begin{array}{l}\text { Decorati } \\
\text { on }\end{array}$} & \multicolumn{2}{|r|}{ Function } \\
\hline & Emic & Etic & $\begin{array}{l}\text { Diam } \\
\text { eter } \\
\text { range }\end{array}$ & $\begin{array}{l}\text { Heigh } \\
\mathrm{t} \\
\text { range }\end{array}$ & & Primary & Secondary \\
\hline $\begin{array}{l}\text { Brewin } \\
\mathrm{g} \\
\text { vessels }\end{array}$ & $\begin{array}{l}\text { Mbizir } \\
o\end{array}$ & $\begin{array}{l}\text { Medium necked } \\
\text { pot with out- } \\
\text { turning rim }\end{array}$ & $\begin{array}{c}28-50 \\
\mathrm{~cm}\end{array}$ & $\begin{array}{c}27-50 \\
\mathrm{~cm}\end{array}$ & $\begin{array}{l}\text { Occasio } \\
\text { nally } \\
\text { decorate } \\
\text { d with } \\
\text { graphic } \\
\text { designs } \\
\text { such as } \\
\text { ribbed } \\
\text { bands }\end{array}$ & $\begin{array}{l}\text { Used for fermenting or } \\
\text { storing mhamba (beer) }\end{array}$ & $\begin{array}{l}\text { Used as a container for drinking } \\
\text { mhamba, especially the type } \\
\text { produced with two mouths }\end{array}$ \\
\hline \multirow[t]{4}{*}{$\begin{array}{l}\text { Storag } \\
\quad \mathrm{e} \\
\text { transp } \\
\text { ortatio } \\
\mathrm{n} \text { and } \\
\text { serving } \\
\text { vessels }\end{array}$} & $\begin{array}{l}\text { Denhe } \\
\text { / } \\
\text { Muzek } \\
\text { a } \\
\text { /Njeka }\end{array}$ & $\begin{array}{l}\text { Large neckless pot } \\
\text { with in sloping rim }\end{array}$ & $\begin{array}{l}27 \\
-45 \\
\mathrm{~cm}\end{array}$ & $\begin{array}{c}40-10 \\
0 \mathrm{~cm}\end{array}$ & $\begin{array}{c}\text { Occasio } \\
\text { nally } \\
\text { decorate } \\
\text { d } \\
\text { graphic } \\
\text { designs }\end{array}$ & $\begin{array}{l}\text { Used as a silo for storing } \\
\text { upfu (maize meal), grain } \\
\text { and legumes such as } \\
\text { mapfunde, rukweza/ } \\
\text { njera, njeke, mhunga, } \\
\text { mupunga (rice), } \\
\text { fondokoto (cowpeas), and } \\
\text { nyimo (ground beans) }\end{array}$ & \\
\hline & $\begin{array}{l}\text { Musud } \\
z e \\
\text { / } \\
\text { Chiron } \\
\text { go } \\
\text { /Pfuko }\end{array}$ & $\begin{array}{l}\text { Small necked pots } \\
\text { with } \\
\text { out-turning rim/ } \\
\text { Large /medium } \\
\text { shouldered pot } \\
\text { with out-turning } \\
\text { rim }\end{array}$ & $\begin{array}{c}24-36 \\
\mathrm{~cm}\end{array}$ & $\begin{array}{c}72-30 \\
\mathrm{~cm}\end{array}$ & $\begin{array}{l}\text { Occasio } \\
\text { nally } \\
\text { decorate } \\
d \text { with } \\
\text { red } \\
\text { ochre } \\
\text { and } \\
\text { graphic } \\
\text { designs } \\
\text { such as } \\
\text { cross } \\
\text { hatching } \\
\text {, and } \\
\text { ribbed } \\
\text { bands }\end{array}$ & $\begin{array}{l}\text { Used for transporting and } \\
\text { storing water }\end{array}$ & $\begin{array}{l}\text { Occasionally used for storing milk, } \\
\text { and transporting mhamba }\end{array}$ \\
\hline & $\begin{array}{l}{ }^{*} \text { Chipf } \\
\text { uko } \\
\text { / } \\
\text { Kapfuk } \\
\text { o } \\
\text { / } \\
\text { kakaha }\end{array}$ & $\begin{array}{l}\text { Small necked pot } \\
\text { with out-turning } \\
\text { rim/Small neckless } \\
\text { pot with out- } \\
\text { turning rim }\end{array}$ & $\begin{array}{c}24-27 \\
\mathrm{~cm}\end{array}$ & $\begin{array}{l}14-26 \\
\mathrm{~cm}\end{array}$ & $\begin{array}{l}\text { Occasio } \\
\text { nally } \\
\text { decorate } \\
\text { d with } \\
\text { red } \\
\text { ochre } \\
\text { and } \\
\text { graphic } \\
\text { designs } \\
\text { such as } \\
\text { cross- } \\
\text { hatching }\end{array}$ & $\begin{array}{l}\text { Used for serving mhamba } \\
\text { (beer) or maheu (sweet } \\
\text { beer) }\end{array}$ & $\begin{array}{l}\text { Used for storing milk (both fresh } \\
\text { and sour) } \\
\text { /Occasionally used for preparing } \\
\text { usavi }\end{array}$ \\
\hline & Nhera & $\begin{array}{l}\text { Semi- } \\
\text { hemispherical } \\
\text { bowl with straight } \\
\text { rim }\end{array}$ & $\begin{array}{c}13-15 \\
\mathrm{~cm}\end{array}$ & $\begin{array}{l}5-7 \\
\mathrm{~cm}\end{array}$ & No & $\begin{array}{l}\text { Used to store munyu } \\
\text { (salt), mafuta (vegetable } \\
\text { or animal fat) and spices } \\
\text { used during cooking }\end{array}$ & Used to store bute (snuff) \\
\hline
\end{tabular}


Fig. 3. Saunyama, Manyika, and Hwesa pottery vessels: $1=$ nhera; $2-4=$ mbiya; 5-7, 8; 6, 7, 9-12 = chipfuko; 13, 16, 19, 23, 24 = mbiziro; 14, 15, 17 = musudze; 18, 21, 22 = gate; 20 = denhe.

Fig 4. Manyika pottery vessels recorded more than 70 years ago by W. H. Stead, a former Native Commissioner of the Nyanga District, north-eastern Zimbabwe (Adapted from Stead 1947:101).

The way pots are classified is mostly based on use. However, they are embodied as women with corresponding body parts (see Collett, 1993; Ndoro, 1996). As demonstrated in Fig. 5, firstly, a pot had a lip (muromo), followed by a neck (mutsipa), shoulder (bendekete), body (dumbu) and, lastly the base (garo). As far as the local potters and consumers were concerned, these anatomical parts were integral in determining the shape of a vessel (also see Martin, 1941; Lawton, 1965). However, from a design and manufacturing point of view use, size and function were correlated variables. Based on this logic, is it possible to apply this classification system to archaeological pottery that is mostly comprised of fragments? We will address this question after considering the dominant archaeological classification system in our region.

Fig. 5. Illustrated Saunyama, Manyika, and Hwesa pottery vessel classes showing varied shapes and sizes in relation to the corresponding anatomical body parts.

\subsection{Typological classification of archaeological pottery}

A total of 26 vessel shapes with varied sizes and rim profiles were typologically reconstructed from the sampled potsherds (Fig. 6). Using the language of archaeologists working in southern Africa, these ranged between pots and bowls (see Tables 3 ). Basically, the assemblage was dominated by small wide-mouthed pots with out-turning rims (22.3\%), followed by large necked bowls with outturning rims (14.56\%), medium wide-mouthed pots with out-turning rims (10.67\%), medium necked pots with out-turning rims (8.73\%), small constricted bowls with in-sloping rims (5.82\%), small open bowls with out-turning rims (5.82\%), small hemispherical bowls with straight rims (4.85\%), Medium necked pots with thickened out-turning rims $(2.91 \%)$, small necked pots with out-turning rims (1.94\%), medium shouldered pots with straight rims (1.94\%), medium shouldered pots with outturning rims (1.94\%), medium constricted pots with in-sloping rims (1.94\%), small necked bowls with out-turning rims (1.94\%), small constricted bowls with out-turning rims $(1.94 \%)$, large necked pots with out-turning rims $(0.97 \%)$, small constricted pots with out-turning rims $(0.97 \%)$, medium constricted pots with out-turning rims $(0.97 \%)$, large wide-mouthed pots with out-turning rims (0.97\%), large hemispherical bowls with straight rims (0.97\%), large deep bowls with straight rims $(0.97 \%)$, large open bowls with straight rims $(0.97 \%)$, large constricted bowls with out-turning rims $(0.97 \%)$, large constricted bowls with in-sloping rims $(0.97 \%)$, small constricted pots with in-sloping rims $(0.97 \%)$, and lastly, large shouldered pots with out-turning rims (0.97\%) (Table 3 ). 
Fig. 6. Part of the reconstructed vessel shapes from the sampled archaeological pottery.

Table 3. Typologies constructed from sampled archaeological pottery.

\begin{tabular}{|c|c|c|}
\hline Vessel Classes & Reconstructed Vessel Shapes & Total \\
\hline $1 a$. & Large necked pots with out-turning rims & 1 \\
\hline $1 \mathrm{~b}$. & Medium necked pots with out-turning rims & 9 \\
\hline 1c. & Medium necked pots with thickened out-turning rims & 3 \\
\hline $1 \mathrm{~d}$. & Small necked pots with out-turning rims & 2 \\
\hline $2 a$. & Large shouldered pots with out-turning rims & 1 \\
\hline $2 b$. & Medium shouldered pots with straight rims & 2 \\
\hline $2 c$ & Medium shouldered pots with out-turning rims & 2 \\
\hline 3a. & Medium constricted pots with in-sloping rims & 2 \\
\hline $3 b$. & Medium constricted pots with out-turning rims & 1 \\
\hline 3c. & Small constricted pots with out-turning rims & 1 \\
\hline $3 d$ & Small constricted pots with in-sloping rims & 1 \\
\hline $4 a$. & Large wide-mouthed pots with out-turning rims & 1 \\
\hline $4 b$. & Medium wide-mouthed pots with out-turning rims & 11 \\
\hline 4c. & Small wide-mouthed pots with out-turning rims & 23 \\
\hline 5. & Small neckless pots with out-turning rims & 2 \\
\hline 6. & Large deep bowls with straight rims & 1 \\
\hline $7 a$. & Large hemispherical bowls with straight rims & 1 \\
\hline $7 \mathrm{~b}$. & Small hemispherical bowls with straight rims & 5 \\
\hline $8 a$. & Large constricted bowls with in-sloping rims & 1 \\
\hline $8 \mathrm{~b}$. & Large constricted bowls with out-turning rims & 1 \\
\hline $8 c$. & Small constricted bowls with in-sloping rims & 6 \\
\hline $8 d$ & Small constricted bowls with out-turning rims & 2 \\
\hline 9a. & Large necked bowls with out-turning rims & 15 \\
\hline $9 b$. & Small necked bowls with out-turning rims & 2 \\
\hline 10a. & Large open bowls with straight rims & 1 \\
\hline 10b. & Small open bowls with out-turning rims & 6 \\
\hline Total & & 103 \\
\hline
\end{tabular}

It is worth mentioning that the reconstructed vessel shapes and sizes (Table 3) matched those identified by previous researchers (i.e. Randall-Maclver, 1906: 1-37; Mason, 1933: 574-578; Martin, 1937; Fripp and Wells, 1938: 399-406; Summers, 1958:140-145; 318-319; Manyanga, 1995; Soper, 2002:251-252; Musindo, 2005; Manyanga and Shenjere, 2012:253).

As part of our study protocol, we took the classification by archaeologists to the groups that we engaged with during the ethnographic phase of our research. First of all, we asked them if they were 
familiar with our twenty-six classes and whether they could identify these types. The result was predictable, the locals expressed unfamiliarity with the labels used to describe the pots. However, when asked to group the pots into classes that they know, most sub-groups disappeared and only the three broad functional classes remained. However, there were some which could not be classified. This persuaded us to combine the local with the established archaeological classification to generate comparison and discussion.

\section{Merging the ethnographic functional typology with the archaeology}

Using the functional typological classes (ethnographic) established for Manyika, Saunyama and Hwesa pottery, we mapped the classes onto the archaeological assemblages based on a reconstruction of full vessels represented by the ceramic sherds. This involved matching shape and size between ethnographic pots and those emerging out of the archaeology. The procedure resulted in the establishment of seven vessel classes from 103 sherds (Table 4 and Fig. 7). The classes that were identified are as follows: mbiya (42\%), chimbiya (22\%), mukate (16\%), musudze (10\%) mbiziro (6\%) chipfuko (3\%), and gate (1\%) (see Table 4).

Table 4. Functional typology of the reconstructed vessels.

\begin{tabular}{lllllllll}
\hline $\begin{array}{l}\text { Functional } \\
\text { Classes }\end{array}$ & Gate & Mbiya & Mukate & Chimbiya & Chipfuko & Mbiziro & Musudze & Total \\
\hline Total & 1 & 43 & 16 & 24 & 3 & 6 & 10 & 103 \\
\hline Frequency & $1 \%$ & $42 \%$ & $16 \%$ & $22 \%$ & $3 \%$ & $6 \%$ & $10 \%$ & $100 \%$ \\
\hline
\end{tabular}

Fig. 7. Functional classes of the reconstructed pottery vessels

Our proximity to communities made it easy to have back and forth engagements with them. For example, we took our classification to elders during focus group discussions for their input and comment. Because elders concurred with our results and in some cases modified then, it became clear that such a classification framework has resonance with contemporary local communities. The major challenge, however, is that this might appear as acts of telescoping the present into the past. This and other discussion points will be considered below.

\section{Discussion: wider archaeological implications}

This experimental study enabled us to correlate the possible shapes and sizes of archaeological pottery sampled from Nyanga tradition sites with those from the modern-day Manyika, Saunyama and Hwesa communities. In particularly it allowed us to piece together the possible functions and uses of the sampled pottery. Because all the reconstructed pottery vessels within the archaeological assemblage were recovered from household contexts and have profiles comparable to Manyika, Saunyama and Hwesa culinary, brewing, storage, transporting and, serving vessels, a similar use can be inferred. Thus, majority of the vessels (Number 2, 4, 6, 7, 8, 9, 10, 11, 12, 16, 25, 26, 27, 29, 30, $31,33,37,43,46,49,50,54,72,75,77,78,92,93,94,101,102)$ likely functioned as culinary ware 
for preparing everyday meals that were consumed by the residents of precolonial Nyanga (see Fig 8). Although this does not preclude the use of the pots in other activities (e.g. ritual), this corresponds with functional patterns we noted during our fieldwork. However, it was beyond the strength of the methodology applied in this pilot study, to identify the exact foods residues that were cooked in these vessels. We will deploy scientific approaches in the next phase of our study. Nevertheless, basing on a comparison with Manyika, Saunyama and Hwesa traditional foodways, meals cooked in these vessels might have included grain and vegetable dishes (Mason, 1933; Martin, 1941; Stead, 1947; Summers, 1958; Lawton, 1965; Gelfand, 1977; Ellert, 1984; Jacobson-Widding, 1992; Maxwell, 1999; Fredriksen, 2009; Nyamushosho, 2019). This speculation must, however, be firmed through the scientific study of residues attached to archaeological pottery.

Fig. 8. Functional classes of the reconstructed Nyanga ware and their frequency (in red).

Furthermore, most of the reconstructed vessels had wide mouths. Probability is very high that such designs were intentionally fashioned by their makers to facilitate steering and pouring of foodstuff. Similarly, thick bottoms on some of the semi-complete vessels (see Fig. 8) distinguish them as cookware. These thick bottoms were intentionally designed to prolong the use-life of most pots as this prevented sudden breakage resulting from surface attrition of both the interior and exterior walls. Culinary vessels with typical features are ubiquitous throughout sub-Saharan African, amongst communities such as the Tiv of Nigeria (Ogundele, 2006), Bafia of central Cameroon (Gosselain, 1992); Mafia of coastal Tanzania (Wynne-Jones and Mapunda, 2009), Tswana of south-eastern Botswana (Thebe and Sadr, 2017), Karanga of south-central and eastern Zimbabwe (Collett 1993; Lindahl and Matenga, 1995; Ndoro 1996); and the Tsonga, Sotho, Venda and Zulu cluster groups in South Africa (Fowler, 2008; Pikirayi and Lindahl, 2013; Fredriksen and Bandama, 2016). In terms of decoration, a few culinary vessels $(26,27,29,102)$, were imprinted with incisions, lattice ridges, and punctates motifs (see marked vessels in Fig. 8). It appears cookware was rarely decorated (Wandibba, 1988), maybe for the reason that it largely served in mundane contexts. Nevertheless, more research is needed to ascertain this proposition which is subject to modification.

Basing on the Saunyama, Manyika, and Hwesa classification of local pottery, the reconstructed largesized necked pots with out-turning rims (Fig. 8) likely functioned as brewing vessels (hari dzedoro) for making alcoholic beverages such as mhamba (millet or sorghum beer) (Martin, 1941; Gelfand, 1977; Nyamushosho, 2012). This is corroborated by the fact that these vessels were designed with necks and out-turning rims to facilitate the pouring of liquids (Ellert, 1984, 2002). This is congruent with ceramic ethnoarchaeological studies carried out amongst Sub-Saharan African communities, such as the Tumtu and Gamo of Ethiopia (Wayessa, 2011; Arthur, 2013), the Twa potters of Rwanda (Kohtamaki, 2010:314), Luo of Kenya (Dietler and Herbich, 2006), Zulu of South Africa (Fowler, 2006, 2008) where brewing pots are designed with larger necks to enable pouring of their liquid contents. The reasons why brewing vessels are few when compared to culinary vessels may be best explained by the fact that consumption of traditional beer is sparingly and treated as luxurious unless during special occasions (Ellert, 1984; Gelfand, 1977). Moreover, as noted by Arthur (2002) from his experiences among the Gamo, because they are large-sized, brewing vessels are generally 'expensive' to make or purchase hence a few wealthier families can own them at the household level. Locally we do have ethnohistorical cases among the broader Shona communities where some households relied on borrowing beer vessels such as gate from other families whenever they wanted to brew (see Gelfand, 1962; Bourdillon, 1976; Zvarevashe, 1976; Hamutyinei, 1989; Chakaipa, 1976; Hanson, 2005; MacGonagole, 2007).

The remainder of the reconstructed vessels which comprise numerous large, medium and smallsized vessels likely served as containers for storing, transporting and serving both liquid and solid 
foods (Fig. 8). Apart from water and beer, the large-sized vessels (3, 14, 23, 24, 28, 38, 45, 49) could have been interchangeably used for storing and transporting processed and unprocessed dried grain such as mapfunde, rukweza/njera and legumes such as fondokoto, and nyimo. Medium and smallsized vessels could have been used to store, transport and serve a range of foodstuffs such as munyu (salt), mafuta (vegetable or animal fat) or zvirungo (spices) mhamba, magada, sadza and usavi (Martin, 1941; Stead, 1947; Lawton, 1965; Gelfand, 1977; Ellert, 1984 Jacobson-Widding, 1992; Fredriksen, 2009). Thus, such varied sizes of storage, transportation, and serving vessels are typical of kitchenware used in most traditional homesteads as recorded elsewhere among the Banda of Ghana (Cruz, 2011).

This experimental study provides archaeologists with possibilities for thinking about classification with the potential to get to daily roles of clay pots in precolonial southern Africa and beyond. For instance, it is by default among the Manyika, Saunyama, and Hwesa that at production (primary) level, the function of any household vessels is determined by the potter, and equally the intended function of the same vessel determines the way it is technically shaped and sized. Similarly, the pattern applies when shifted to the consumption (secondary) level where the consumer determines both the primary and secondary functions of the same vessel in the light of its shape and size. Thus, unlike us archaeologists who value pottery style and decoration as key attributes for pottery classification; to the Manyika, Saunyama and Hwesa and their compatriots what matters most about a vessel is its faculty to serve the intended function since the making of any clay pot vessel is primarily inspired by a need. Accordingly, the potter considers the shape and size to fashion the appropriate vessel whilst, other attributes such as decoration come as secondary considerations. This is common among sub-Saharan autochthons such as the Banda (Cruz, 2011), Zulu (Fowler, 2008), Gamo (Arthur, 2002, 2013), Tiv (Ogundele, 2009), Luo (Dietler, 2001), Venda (Pikirayi and Lindahl, 2013), Karanga (Collett 1993; Lindahl and Matenga, 1995; Ndoro, 1996), Tswana (Thebe and Sadr, 2017), and the Twa (Kohtamaki, 2010) where vessel decorations play an insignificant role in determining local vessel taxonomy. Thus, functional typologies apply to a wide range of pottery be it from southern Africa, West Africa or East Africa.

These dynamics motivate for alternative ways of looking at archaeological pottery. Furthermore, it also exposes the incapacity of etic classification schemes rooted in Anglo-American analytical methods of ceramic analysis, to consider possible uses of pottery. This highlights the need for combining approaches as attempted in this study. It is important to complement existing data on typologies based on decorative style with functional typologies to access everyday uses of pottery. More so, because Iron Age ceramics in southern Africa were hand-crafted, there is room for independent innovations and experiments in terms of stylistic designs which probably ranged from one potter to another. For instance, as illustrated in Fig. 9, it is plausible that archaeological vessels sampled in this study likely comprised of a few vessel categories with shapes and sizes that varied. Thus, the application of a stylistic typological framework to the sampled sherds from the Nyanga archaeological complex created more vessel classes (which summed to 26, see Table 2) with unknown functions. Alternatively, only three functional categories (Fig. 8) were recreated using the local classification method, and these intersect with vessel classes common in African homesteads (see Lawton, 1965; Ellert, 1984; Aschwanden 1989; Gosselain 1992; Collett, 1993; Lindahl and Matenga, 1995; Ndoro, 1996; Dietler, 2001; Arthur, 2002, 2013; Kohtamaki, 2010; Cruz, 2011 Lindahl and Pikirayi, 2013). Thus, such a huge difference in priorities and outcomes demonstrates the need to combine techniques to access multiple aspects of the past (Beach, 1980; Hall, 1984; Ndoro, 1996) including the roles clay pots played in the daily lives of communities that made and consumed them.

Fig. 9. Multidimensional functional classification of the reconstructed vessels based on shape and size. 
It must also be acknowledged that Huffman's typological method is partly based on the local system of classification and partly on archaeological intuition (see Huffman 1972). The method however uses jargon and terminology pivoted on western philosophy and has been criticised for excluding local meanings (see Hall 1983; Collett 1993). As shown in Fig 9, a multi-dimensional classification can also accommodate shape, size, style, and function in native cosmologies and meanings. However, one of the reasons why dominant typological classifications in southern Africa are often criticised is that they use terminology and concepts that are not local (see Table 5). This creates new categories whose meanings are at odds with how natives and their ways of knowing perceive the same artefacts. For example, to the natives, clay pots form part of a universe of material culture, finding use across a range of activities in the kitchen and outside of it (Collett, 1993; Lindahl and Matenga, 1995; Ndoro, 1996) or even those from sub-Saharan Africa (Gosselain 1992; David and Kramer, 2001; Dietler, 2001; Arthur, 2002, 2013; Kohtamaki, 2010; Cruz, 2011). So, in a way, because different classifications are designed to achieve different objectives, it is essential to combine etic with emic systems to produce meanings with local and archaeological resonance and relevance.

Table 5 Common archaeological pottery names, Shona translations and local names of different categories of pottery

\begin{tabular}{|c|c|c|c|}
\hline \multirow[t]{2}{*}{ Vessel ID } & \multicolumn{2}{|c|}{ Typological Class } & \multirow{2}{*}{$\begin{array}{l}\text { Functional Class } \\
\text { Emic names in } \\
\text { local language }\end{array}$} \\
\hline & $\begin{array}{l}\text { Etic terms using the language of } \\
\text { archaeologists }\end{array}$ & $\begin{array}{l}\text { Translation of the etic names in } \\
\text { local language }\end{array}$ & \\
\hline 1 & $\begin{array}{l}\text { Large necked pot with out- } \\
\text { turning rim }\end{array}$ & $\begin{array}{l}\text { Hari hombe ine huro nemuromo } \\
\text { wakadaukira }\end{array}$ & Gate \\
\hline 2 & $\begin{array}{l}\text { Medium constricted pot with } \\
\text { out-turning rim }\end{array}$ & $\begin{array}{l}\text { Hari iri pakati nepakati } \\
\text { yakambunyikidza ine muromo } \\
\text { wakadaukira }\end{array}$ & Mbiya \\
\hline 14 & $\begin{array}{l}\text { Medium necked pot with out- } \\
\text { turning rim }\end{array}$ & $\begin{array}{l}\text { Hari iri pakati nepakati ine huro } \\
\text { ne muromo wakadaukira }\end{array}$ & Chipfuko \\
\hline 15 & $\begin{array}{l}\text { Medium necked pot with out- } \\
\text { turning rim }\end{array}$ & $\begin{array}{l}\text { Hari iri pakati nepakati ine huro } \\
\text { ne muromo wakadaukira }\end{array}$ & Mbiziro \\
\hline 28 & $\begin{array}{l}\text { Medium necked pot with out- } \\
\text { turning rim }\end{array}$ & $\begin{array}{l}\text { Hari iri pakati nepakati ine huro } \\
\text { ne muromo wakadaukira }\end{array}$ & Musudze \\
\hline 98 & $\begin{array}{l}\text { Small wide-mouthed pot with } \\
\text { out-turning rim }\end{array}$ & $\begin{array}{l}\text { Hari doko dhafu ine muromo } \\
\text { wakadaukira }\end{array}$ & Chimbiya \\
\hline
\end{tabular}

If the goal of archaeology is to produce knowledge of the past with local relevance, then it is essential to use local concepts in the analysis. In making this statement, we are alert to the fact that dynamism of practice characterised human behaviour and that innovation and improvisation are features of human life. Consequently, it is possible that some archaeological shapes may not have had the same names, let alone function as ethnographic pottery but this creates a past that is locally relevant and meaningful. It factors in concerns of archaeologists and those of communities, particularly the long excluded indigenous groups. Also, there is a massive potential for scientific studies to contribute to these discussions, through petrographic studies of clays and residue analyses (see Skibo, 1992, 2013).

\section{Conclusion}


While stylistic typologies of pottery have significantly expanded the frontiers of knowledge about the culture-history of Iron Age societies in Nyanga and elsewhere; there are several limitations owing to failure to address the local meanings of pottery embedded in local classification systems. This has resulted in the creation of multidimensional pottery seriations that prioritised pottery style and decoration as if the same pottery was not active in everyday life. Our experimental study has demonstrated the potential of the functional analysis approach towards capturing these relegated meanings hence revealing wide-ranging quotidian roles and functions that pottery probably fulfilled in precolonial Nyanga. More importantly, we now know that the shapes and sizes of ancient pottery vessels strongly correlated with their names and functions in both domestic and ritual contexts of everyday life. Thus, in as much as functional typologies, are subject to cultural continuity and change, they are more viable for meaningful ceramic studies, particularly when combined with style. Unlike the conventional classification schemes rooted in Anglophone approaches to ceramic analysis, functional typologies give more insight on the people than the pottery. As our research develops, we will apply techniques from material and molecular sciences to understand properties of clays, and to identify foods that were cooked inside the pots. Also, to compare to the typological pictures with other assemblages.

\section{Acknowledgements}

This paper is part of the special issue, "Africa under the microscope: What's the future for technofunctional analysis?". We are grateful to Guilio Lucarini and Sonja Tomasso for inviting us to contribute. Special thanks goes to the Manyika, Saunyama and Hwesa communities in Nyanga who made this study possible. We thank Robert Soper, Martin Hall, and the two anonymous reviewers for their valuable comments, and insights. Instutional support from the University of Cape Town is acknowledged with sincere gratitude.

\section{References}

Arnold, D. E., and Nieves, A. L. 1992. Factors affecting ceramic standardization. In Bey, G. J., III, and Pool, C. (eds.), Ceramic Production and Distribution: An Integrated Approach. Boulder. Westview Press.

Aschwanden H. 1989. Karanga Mythology, Gweru: Mambo Press.

Arthur, J. W. 2002. Pottery use-alteration as an indicator of socio-economic status: An ethnoarchaeological study of the Gamo of Ethiopia. Journal of Archaeological Method and Theory. (9): 331-355.

Arthur, J. W. 2013. Transforming clay: Gamo caste, gender, and pottery of south western Ethiopia. African Study Monographs, Suppl. 46: 5-25.

Fredriksen, P.D. and Bandama, F. 2016. The mobility of memory: space/knowledge dynamics in rural potting workshops in Limpopo Province, South Africa. Azania: Archaeological Research in Africa 51: 1-18.

Beach, D. N. 1980. The Shona and Zimbabwe: 1900-1850. Gweru: Mambo Press.

Beach, D. N. 2002. History and archaeology in Nyanga. In Nyanga: Ancient Fields, Settlements and Agricultural History in Zimbabwe. Soper, R. Memoirs of the British Institute in Eastern Africa: Number 16. London: British Institute in East Africa. 
Bhila, H. H. K. 1982. Trade and politics in a Shona kingdom: The Manyika and their African and Portuguese neighbours, 1575-1902. Essex: Longman, Harlow.

Bourdillon, M.F.C. 1976.The Shona Peoples: An Ethnography of the Contemporary Shona with Special Reference to their Religion. Mambo Press: Gweru.

Chakaipa, P. 1976. Pfumo reropa. Harare: Longman Zimbabwe.

Chirikure S., Nyamushosho, R T., Chimhundu, H.H., Dandara, C., Pamburai, H.H. and Manyanga, M. 2017. Concept and knowledge revision in the post-colony: mukwerera, the practice of asking for rain amongst the Shona of southern Africa. In Manyanga, M and Chirikure, S (eds), Archives, Objects and Landscapes. Multidisciplinary approaches to Decolonised Zimbabwean Pasts. Langaa Publishers.

Collett, D.P. 1993. Metaphors and Representations Associated with Pre-colonial Iron Smelting in Eastern and Southern Africa', in T. Shaw, P. Sinclair, B. Andah and J. Okpoko (eds) The Archaeology of Africa: Food, Metals and Towns, London: Routledge.

Cruz, M.D. 2011. "Pots are pots, not people": material culture and ethnic identity in the Banda Area (Ghana), nineteenth and twentieth centuries', Azania: Archaeological Research in Africa, 46(3): 336-357. DOI: 10.1080/0067270X.2011.629525.

David, N., Sterner, J., Gavua, K., 1988. Why pots are decorated. Current. Anthropolology. 29 (3),

365-389.David N. and Kramer C. 2001. Ethnoarchaeology in action, Cambridge. Cambridge University Press.

Denbow, J. R. 1983. "Iron Age economics: herding, wealth and politics along the fringes of the Kalahari Desert during the Early Iron Age." PhD diss., Indiana University.

Dietler, M. 2001. Theorizing the feast: Rituals of consumption, commensal politics, and power inAfrican contexts, in M. Dietler and B. Hayden (eds), Feasts: Archaeological and ethnographic perspectives on food, politics, and power (Washington DC: Smithsonian InstitutionPress), pp. 65-114.

Dietler, M. and Herbich, I. 2006. Liquid Material Culture: Following the Flow of Beer Among the Luo of Kenya.In Grundlegungen. Beiträge zur europäischen und afrikanischen Archäologie für ManfredK. H. Eggert,edited by Hans-Peter Wotzka, pp. 395-408. Francke Verlag, Tübingen, Germany.

Ellert, H. 1984. Material Culture of Zimbabwe. Harare: Longmans.

Ellert, H. 2002. Traditional African Art of Zimbabwe. Lusaka. CBC Publishing.

Fowler, K. D. 2002. Early Iron Age community organization in southern Africa: Social and symbolic dimensions of ceramic production, use and discard at Ndondondwane. PhD Dissertation, Edmonton. University of Alberta.

Fowler, K.D. 2006. Classification and collapse: the ethnohistory of Zulu ceramic use. Southern African Humanities 18: 93-117. 
Fowler, K.D. 2008. Zulu pottery production in the Lower Thukela Basin, KwaZulu-Natal, South Africa. Southern African Humanities 20: 477-511.

Fredriksen, P.D. 2009. Transformations in clay: Material Knowledges, Thermodynamic Spaces and the Moloko Sequence of the Late Iron Age (AD 1300-1840) in Southern Africa. PhD Dissertation, Norway. University of Bergen.

Fredriksen, P. D. and Chirikure, S. 2015. Beyond Static Models: An Evaluation of Present Status and Future Prospects for Iron Age Research in Southern Africa. Cambridge Archaeological Journal. CJO 2015 doi:10.1017/S0959774314001115.

Fredriksen, P. D. and F. Bandama. 2016. The Mobility of Memory: Space/Knowledge Dynamics in Rural Potting Workshops in Limpopo Province, South Africa. Azania: Archaeological Research in Africa 51 (4): 489-506.

Fripp, C. and Wells, L.H. 1938. Excavations in a pit circle at Inyanga, S. Rhodesia. South African Journal of Science. 35: 399-406.

Gelfand, M. 1974. "The Mhondoro cult among the Manyika peoples of the eastern region of Mashonaland," NADA 11: 64-95.

Gelfand, M. 1977. The spiritual beliefs of the Shona: A study based on a field work among the East Central Shona. Gweru: Mambo Press.

Gelfand, M., Mavi, S., Drummond, R.B. and Ndemera, B. 1985. The Traditional Medical Practitioner in Zimbabwe: His Principles of Practice and Pharmacopoeia. Gweru: Mambo Press.

Gosselain, O.P. 1992. Technology and style: Potters and pottery among Bafia of Cameroon. Man 27(3): 559-586.

Hall, M. 1983. Tribes, traditions and numbers: The American model in southern African Iron Age ceramic studies. South African Archaeological Bulletin. 38: 51-57.

Hall, M. 1984. Pots and politics: ceramic interpretations in southern Africa. World Archaeology 15 (3): 262-273.

Hamutyinei, M.A. 1989. Musango munenyama, Harare: Longman.

Hanson, B. 2005. Takadini. Harare. Fidalyn Productions.

Huffman, T.N. 1972. Shona pottery from Pumula Township, Bulawayo, Rhodesia. South African Archaeological Bulletin, 27: 66-81.

Huffman, T. N. 2007. Handbook to the Iron Age: The Archaeology of Pre-colonial Farming Societies in Southern Africa. Southville. University of KwaZulu-Natal Press.

Jacobson-Widding, A. 1992. Pits, Pots and Snakes: An Anthropological Approach to Ancient African Symbols Nordic Journal of African Studies. 1(1): 5-25. 
Kohtamaki, M. 2010. An ethnoarchaeological study of Twa potters in southern Rwanda, Azania: Archaeological Research in Africa. 45:3, 298-320.

Lawton, A. 1965. Bantu pottery of Southern Africa Volume 1. MA Dissertation. Cape Town: University of Cape Town.

Lindahl, A. and Matenga, M. 1995. Present and past: Ceramics and homesteads: An ethnoarchaeological study in the Buhera district, Zimbabwe. Studies in African Archaeology 11. Department of Archaeology. Uppsala: Uppsala University.

Pikirayi, I. and Lindahl, A. 2013. Ceramics, Ethnohistory, and Ethnography: Locating Meaning in Southern African Iron Age Ceramic Assemblages. African Archaeological Review. 30: 455 473.

MacGonagle, E. 2007. Crafting identity in Zimbabwe and Mozambique, New York: University of Rochester Press.

Manyanga, M. 1995. Nyanga pottery: a classification of the lowland and upland ruin wares. BA Dissertation. University of Zimbabwe, Harare.

Manyanga, M. and Shenjere, P. 2012. The archaeology of the northern Nyanga lowlands and the unfolding farming community sequence in northeastern Zimbabwe. South African Archaeological Bulletin. 67: 244-255.

Martin, C. 1937. Prehistoric burials at Penhalonga. South African Journal of Science. 33: 1037-43.

Martin, C. 1941. Manyika pottery. Proceedings of the Rhodesian scientific association. 38: 52-62.

Mason, A, Y. 1933. The Penhalonga Ruins. S, Rhodesia. South African Journal of Science. 30:559-581.

Maxwell, David. 1999. Christians and Chiefs in Zimbabwe: A Social History of the Hwesa People c. 1870s-1990s. Edinburgh: Edinburgh University Press.

Mupira P. 2001. Local histories, oral traditions and the archaeological landscape in Nyanga district, north-east Zimbabwe, Zimbabwean Prehistory, 24: 14-21.

Musindo T. 2005. An analysis of prehistoric pottery from Murahwa's Hill, Mutare. BA Honours Dissertation. University of Zimbabwe.

Mtetwa, E., Manyanga, M. and Pikirayi, I. 2013. Ceramics in Zimbabwean archaeology: Thinking beyond the traditional approaches. In Zimbabwean archaeology in the Post-independence era. M. Manyanga and S. Katsamudanga, Eds. Harare: Sapes books.

Ndoro, W. 1996. Towards the meaning and symbolism of archaeological pottery assemblages. In Aspects of African Archaeology: Papers from the 10th Pan African Association for Prehistory and Related Studies. G. Pwiti and R. Soper, Eds. Harare: University of Zimbabwe Publications.

Nyamushosho R, T. 2012. Ethnoarchaeological study of pottery vessels from, northeastern Zimbabwe. Unpublished field notes. 
Nyamushosho, R, T. 2013. Identity and Connections: An ethnoarchaeological study of pottery vessels from the Saunyama dynasty and the Nyanga archaeological complex in northeastern Zimbabwe. BA Honours Dissertation. Gweru. Midlands State University.

Nyamushosho, R.T. 2014. Ceramic ethnoarchaeology in Zimbabwe. International Research Journal of Arts and Social Sciences. 3(2): 17-25.

Nyamushosho, R T. 2017. Aspects of consumption and symbolism: A ceramic ethnoarchaeological study of ritual vessels among the Saunyama of north-eastern Zimbabwe In Manyanga, $M$ and Chirikure, S (eds), Archives, Objects and Landscapes. Multidisciplinary approaches to Decolonised Zimbabwean Pasts. Langaa Publishers.

Nyamushosho, R.T. 2019. Nyanga pottery and the Manyika: Towards a decolonised archaeology of the Nyanga complex (CE 1300-199). Paper presented at the Uuniversity of Cape Town Centre for African Studies Engaged Scholarship in Africa: A tribute to Samir Amin Conference, Cape Town, 19-20 September 2019.

Ogundele S, O. 2006. Prospects and Challenges of oral traditions and ethnography for archaeological reconstructions: A case study of Tivland, Nigeria. Anistoriton Journal. 10: 1-13.

Phillipson, D. W. 2005. African archaeology. Cambridge: Cambridge University Press.

Pikirayi, I. 1993. The Archaeological Identity of the Mutapa State: Towards a historical archaeology of northern Zimbabwe. Studies in African Archaeology 6. Uppsala. Societas Archaeologica Uppsaliensis.

Pikirayi I. 1997. Pots, people and culture: an overview of ceramic studies in Zimbabwe'. In: Pwiti, G. (ed.) Caves, Monuments and Texts: Zimbabwean Archaeology Today, Uppsala: Societas Archaeologica Uppsaliensis.

Pikirayi, I. 2001. The Zimbabwe Culture: Origins and Decline of Southern Zambezian States. Walnut Creek: AltaMira Press.

Pikirayi, I. 2007. Ceramics and group identities: Towards a social archaeology in Southern African Iron Age ceramic studies. Journal of Social archaeology. 7(3): 286-301.

Pikirayi I, and Lindahl A. 2013. Ceramics, Ethnohistory, and Ethnography: Locating Meaning in Southern African Iron Age Ceramic Assemblages. African Archaeological Review. 30: 455 473.

Posnansky, M. 1961, Iron Age in east and central Africa: points of comparison. South African Archaeological Bulletin 16:134-136.

Pwiti, G. 1996. Continuity and Change: An Archaeological Study of Farming Communities in Northern Zimbabwe, AD 500-1700. Uppsala: Societa Archaeologica Uppsaliensis.

Thebe, P.C. and Sadr, K. 2017. Forming and shaping pottery boundaries in contemporary south eastern Botswana. African Archaeological Review 34: 75-92.

Randall-Mclver, D. 1906. Medieval Rhodesia. London: McMillan. 
Robinson, K, R. 1966. The Leopard's Kopje culture: its position in the Iron Age in Southern Rhodesia. South African Archaeological Bulletin 21: 5--51.

Schofield, J.F. 1948. Primitive Pottery, an introduction to South African ceramics, prehistoric and protohistoric. Cape Town: South African Archaeological Society.

Shenjere, P 2011. The animal economy of prehistoric farming communities of Manicaland, eastern Zimbabwe. PhD thesis. University of Dar es Salaam, Tanzania.

Skibo, J. M. 1992. Pottery Function. Plenum, New York.

Skibo, J. M., 2013. Understanding Pottery Function. Springer, New York.

Sinclair, P. J. J. 1987. 1987. Space, Time and Social Formation: A Territorial Approach to the Archaeology and Anthropology of Zimbabwe and Mozambique, c. 0--1700 A.D. Uppsala: Societas Archaeologica Upsalensis

Soper, R. 1971. A general review of the Early Iron Age in the southern half of Africa. Azania. 6: 5-37.

Soper, R. 2002. Nyanga: Ancient Fields, Settlements and Agricultural History in Zimbabwe. Memoirs of the British Institute in Eastern Africa: Number 16. London: British Institute in East Africa.

Stead, W. H. 1947. Notes on the types of clay pots found in the Inyanga District, 1945, identified from specimens collected for the purpose by native messengers at office of Native Commissioner, Inyanga. NADA, 24, 100-102.

Summers, R. 1958. Inyanga: Prehistoric settlements in Southern Rhodesia. Cambridge: Cambridge University Press.

Wandibba, S. 1988. On why pots are decorated the way they are. Current Anthropology, 29(5), 739741.

Wayessa, B S. 2011. The Technical Style of Wallaga Pottery Making: An Ethnoarchaeological Study of Oromo Potters in Southwest Highland Ethiopia. African Archaeological Review 28, No. 4: 301-326.

Wynne-Jones, S. and Mapunda, B. 2008. 'This is what pots look like here': ceramics, tradition and consumption on Mafia Island, Tanzania. Azania: Archaeological Research in Africa. 43: 1, 1-17, DOI: 10.1080/00672700809480456.

Zvarevashe, I.M. 1976. Kurauone, Harare: College Press. 